\title{
The Effectiveness of Health Management-Assisted Technology on Glycated Hemoglobin Levels in Patients with Type 2 Diabetes Mellitus: Meta-Analysis
}

\author{
Fajar Novianto'), Atika Mima Amalin²), Anggun Fitri Handayani3), Anggraini \\ Ambarsari4), Diana Ode5), Alfi Makrifatul Azizah6), Ayu Trisni Pamilih7), Annisa \\ Fitriana Damalita ${ }^{8)}$, Fathiyyatu Assa'diy Firda9), Ahmad Syauqi Mubarok10) \\ ${ }^{1)}$ National Institute of Health Research and Development,Indonesian Ministry of Health \\ ${ }^{2)}$ Health Polytechnic Jember, East Java \\ 3)School of Health Sciences Karya Husada Semarang, Central Java \\ ${ }^{4)}$ Gadjah Mada University. Yogyakarta \\ 5) Respati University, Yogyakarta \\ 6) Ahmad Dahlan University Yogyakarta \\ 7)Health Polytechnics, Ministry of Health Surakarta, Central Java \\ ${ }^{8)}$ School of Health Sciences Aisyiyah, Yogyakarta \\ 9) Muhammadiyah University, Surakarta, Central Java \\ ${ }^{10)}$ School of Health Sciences Kusuma Husada, Surakarta, Central Java
}

\section{ABSTRACT}

Background: Given the number of patients failing to achieve control of Diabetes Mellitus (DM), it causes an increase in the incidence of DM complications. Along with the rapid development of technology in this era, this study aimed to prove the effectiveness of technologybased health management compared to usual treatment for levels glycated hemoglobin (HbA1c) in type 2 diabetes mellitus patients.

Subjects and Method: This was a meta-analysis using a randomized controlled trial. Articles were obtained from PubMed, Google Scholar, and ResearchGate databases. The articles used in this study were those published from 2012-2021. The search article was carried out by considering the eligibility of the criteria determined using the PICO model. Population: type $2 \mathrm{DM}$ patients (HbA1c $>7 \%$ ), Intervention: health management-assisted technology, Comparison: usual care Outcome: HbA1c levels. There were 10 articles used with a sample size of 1693 people who were divided into two groups (845 people in the health managementassisted technology group and 848 people in the group usual care). Articles were analyzed using Review Manager 5.3 Application to determine the Standard Mean Difference (SMD) and heterogeneity of the study sample.
Results: From 10 articles that were processed using RevMan 5.3, significant results were obtained, this is indicated by the overall effect (diamond) which does not touch the vertical line Ho $(\mathrm{d}=0)$ and can also be seen from the $95 \%$ CI range of -0.62 to -0.13 which shows significant because it does not pass the number $\mathrm{o}(\mathrm{SMD}=-0.37 ; 95 \% \mathrm{CI}=-0.62$ to $-0.13 ; \mathrm{p}=$ o.o03). The heterogeneity of the research data shows $\mathrm{I}^{2}=82 \%$ so that the distribution of the data is very heterogeneous (random effects model).

Conclusion: Using technology to help health management of patients with type 2 diabetes mellitus can reduce HbA1c levels compared to usual care.

Keywords: Health management, technology, diabetes mellitus, HbA1c

\section{Correspondence:}

Fajar Novianto. Center for Research and Development of Medicinal Plants and Traditional Medicine, National Institute of Health of Health, Jl. Raya Lawu No. 11 Karanganyar, Central Java. Email: dr.fajarnovianto@gmail.com.

Cite this as:

Novianto F, Amalin AM, Handayani AF, Ambarsari A, Ode D, Azizah AM, Pamilih AT, Damalita AF, Firda FA, Mubarok AS (2021). The Effectiveness of Health Management-Assisted Technology on Glycated 
Novianto et al./ Health Management-Assisted Technology on Glycated Hemoglobin Levels

Hemoglobin Levels in Patients with Type 2 Diabetes Mellitus: Meta-Analysis. J Health Policy Manage. 06(01): 81-93. https://doi.org/10.26911/thejhpm.2021.06.02.01.

cc (i) (-) Journal of Health Policy and Management is licensed under a Creative Commons Attribution-NonCommercial-ShareAlike 4.o International License.

\section{BACKGROUND}

Diabetes mellitus (DM) is a chronic disease that occurs when the pancreas does not produce enough insulin or when the body cannot effectively use the insulin it produces diabetes is found in every population in the world and in all regions, including the rural parts of middle-income countries. The number of people with diabetes continues to increase, the World Health Organization (WHO) estimates that there are 422 million adults with diabetes worldwide in 2014. Without intervention to stop the increase in diabetes, at least 629 million people will live with diabetes by 2045 (WHO, 2019).

Diabetes mellitus poses significant social and economic burdens, because elevated glycosylated hemoglobin (HbA1c) is associated with high morbidity and mortality rates due to multiorgan complications. Although several effective therapies are available to increase HbA1c, many patients fail to achieve control of Diabetes Mellitus (Fountoulakis et al., 2015). The increased incidence of type 2 diabetes mellitus has broad implications for the health status of the population and the increase in health care costs (Crowley et al., 2016; Tang et al., 2013). However, better control will reduce the incidence of diabetes complications. Patients with persistently uncontrolled diabetes mellitus, or maintaining $\mathrm{HbA1c}>9.0 \%$ for $>1$ year are the targets and high priority for administering an intervention (Crowley et al., 2016).

In the United States, several health facilities have developed disease management systems online to support diabetes patients as part of a personalized health care program or PHCP (Personalize Health- care Program). PHCP incorporates several features of an effective disease management program, including multidisciplinary team-based care, use of Nurse Care Managers authorized (NCM) to transform medications, tools for patient self-management, and online communication channels between patients and teams of healthcare professionals (Tang et al., 2013).

For this reason, a new method is needed for health workers to partner with patients in managing diabetes which emphasizes the use of a multidisciplinary team of health workers and active patients (Heisler et al., 2014; Tang et al., 2013), a personal health record that integration will increase the ease with which patients can access their data and facilitate communication with a team of healthcare professionals. In contrast to follow-up visits, remote monitoring technology and automatic alerts and communication capabilities can support better continuity of care (Tang et al., 2013) so as to improve glycemic control of glycated hemoglobin (HbA1c) in patients with type 2 diabetes mellitus compared with regular care provided directly by health workers (Nicolucci et al., 2015). Along with the rapid development of technology in this era, this study aimed to prove the effectiveness of technology-based health management compared to usual treatment for levels glycated hemoglobin (HbA1c) in type 2 diabetes mellitus patients.

\section{SUBJECTS AND METHOD}

\section{Study Design}

This study was a systematic review and meta-analysis. The articles used in this study were obtained from several databases 
including PubMed, Google Scholar, and ResearchGate. The keywords to look for articles are as follows: type 2 diabetes mellitus AND (health technology OR mhealth) AND (glycated hemoglobin OR HbA1c) AND Randomized Controlled Trial.

\section{Inclusion Criteria}

The articles include in this study were full text and in English with randomized controlled trials design. Article presents a comparison between the use of technology and normal routine maintenance.Subjects were people with type 2 diabetes mellitus. The HbA1c level of subjects before the study was $>7 \%$. Minimum study duration 3 months (12 weeks). Displays the mean and standard deviation (SD) of HbA1c levels at the end of the study and articles published between 2012-2021

\section{Exclusion criteria}

Articles included patients with type 1 diabetes mellitus and articles that in the recruitment of subjects did not require HbA1c levels $>7 \%$.

4. Operational Definition of Variables Article searches were performed by considering eligibility criteria determined using the PICO model (Population, Intervention, Comparison, Outcome). The population in this study were patients with type 2 diabetes mellitus with HbA1c levels $>7 \%$, interventions in the form of the use of health technology (health managementassisted technology), comparison with those receiving usualcare and the results showed HbA1c levels.

Diabetes mellitus type 2 is a metabolic disorder characterized by an increase in blood sugar due to decreased insulin secretion by pancreatic beta cells and / or disruption of insulin function (insulin resistance) (WHO, 2019).

Health technology is technology that is used to assist patient health management, which can be based on the internet, applications, videos, or communication technology.

Usual care is caringthat patient get on a regular basis as before the study was conducted.

HbA1c is a non-enzymatic bond of glucose molecules to hemoglobin through a posttranslation glycation process. HbA1c level examination is recommended by the American Diabetic Association (ADA) for controlling diabetes mellitus patients because it can describe the average blood sugar over the last 2-3 months so that it can be used as a reference for treatment planning (Ramadhan and Marissa, 2015).

\section{Data analysis}

Processing uses the Review Manager (RevMan 5.3) application by calculating the effect size and heterogeneity which is a combination of study models and forms a final meta-analysis of results.

\section{RESULTS}

The process of searching for articles through the journal database can be seen in Figure 1. Figure 2 shows the areas where articles were taken according to the inclusion criteria. The articles obtained consisted of 10 articles whose research subjects came from the United States, Italy, India, Germany and the United Kingdom.

An overview of the primary studies that qualify for meta-analysis can be seen in Table 1, while the critical appraisal of each study can be seen in Table 2 . 
Novianto et al./ Health Management-Assisted Technology on Glycated Hemoglobin Levels

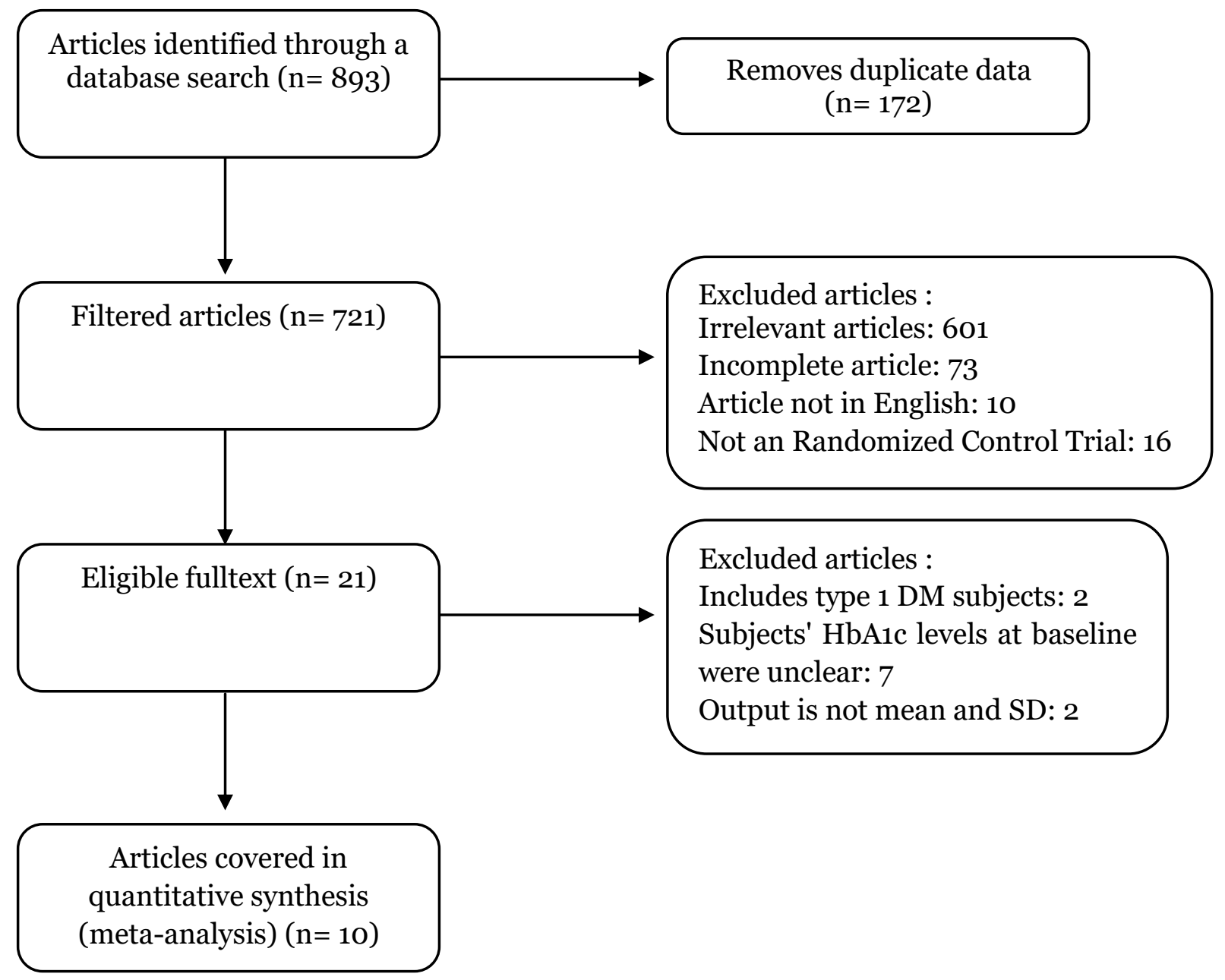

Figure 1. PRISMA diagram

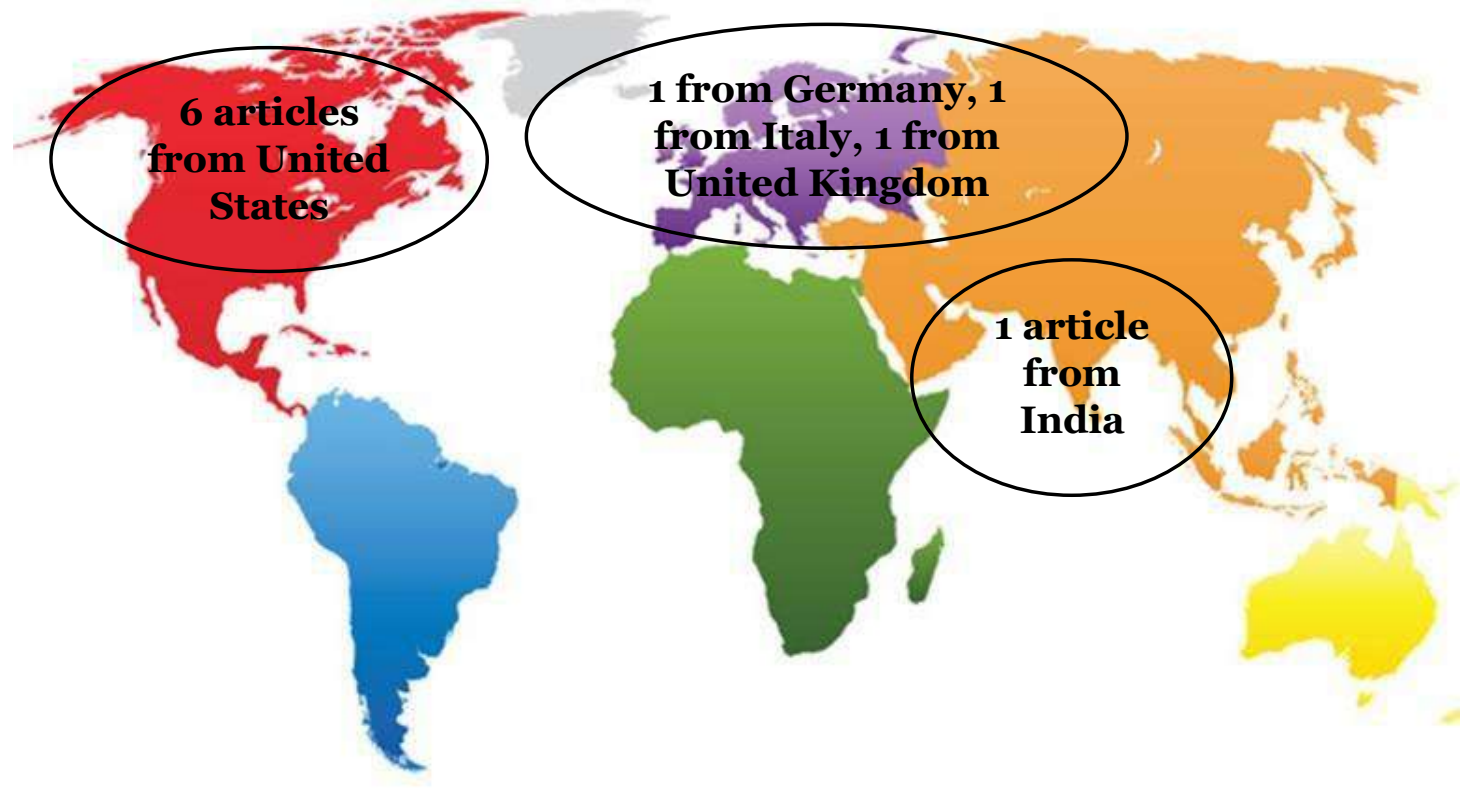

Figure 2. Research area 
Table 1. Critical appraisal for randomized controlled trials

\begin{tabular}{|c|c|c|c|c|c|c|c|c|c|c|}
\hline Questions & $\begin{array}{l}\text { Crowley } \\
\text { et al., } \\
2016\end{array}$ & $\begin{array}{l}\text { Heisler } \\
\text { et al., } \\
2014\end{array}$ & $\begin{array}{c}\text { Hsu et } \\
\text { al., } 2016\end{array}$ & $\begin{array}{l}\text { Kempf et } \\
\text { al., } 2017\end{array}$ & $\begin{array}{l}\text { Kleinman } \\
\text { et al., } 2017\end{array}$ & $\begin{array}{l}\text { Klingeman } \\
\text { et al., } 2017\end{array}$ & $\begin{array}{l}\text { Nicolucci } \\
\text { et al., } \\
2015\end{array}$ & $\begin{array}{c}\text { Tang et } \\
\text { al., } 2013\end{array}$ & $\begin{array}{l}\text { Tildesley } \\
\text { et al., } \\
2013\end{array}$ & $\begin{array}{l}\text { Wild et } \\
\text { al., } 2016\end{array}$ \\
\hline $\begin{array}{l}\text { Does the } \\
\text { experiment } \\
\text { answer the } \\
\text { problem } \\
\text { clinical clear? }\end{array}$ & Yes & Yes & Yes & Yes & Yes & Yes & Yes & Yes & Yes & Yes \\
\hline $\begin{array}{l}\text { Was the } \\
\text { intervention } \\
\text { to the patient } \\
\text { randomized? }\end{array}$ & Yes & Yes & Yes & Yes & Yes & Yes & Yes & Yes & Yes & Yes \\
\hline $\begin{array}{l}\text { Are blinding } \\
\text { patients, } \\
\text { health work- } \\
\text { ers, and } \\
\text { researchers? }\end{array}$ & open-label & $\begin{array}{c}\text { Double } \\
\text { blind }\end{array}$ & open-label & $\begin{array}{l}\text { Single } \\
\text { blind }\end{array}$ & open-label & open-label & open-label & $\begin{array}{l}\text { Single } \\
\text { blind }\end{array}$ & open-label & $\begin{array}{l}\text { Single } \\
\text { blind }\end{array}$ \\
\hline $\begin{array}{l}\text { Were the } \\
\text { study groups } \\
\text { similar at the } \\
\text { start of the } \\
\text { study? }\end{array}$ & Yes & Yes & Yes & Yes & Yes & Yes & Yes & Yes & Yes & Yes \\
\hline $\begin{array}{l}\text { Outside of } \\
\text { the interven- } \\
\text { tions studied, } \\
\text { were the } \\
\text { study groups } \\
\text { treated the } \\
\text { same? }\end{array}$ & Yes & Yes & Yes & Yes & Yes & Yes & Yes & Yes & Yes & Yes \\
\hline $\begin{array}{l}\text { Were all pati- } \\
\text { ents included } \\
\text { in the study } \\
\text { appropriately }\end{array}$ & Yes & Yes & Yes & Yes & Yes & Yes & Yes & Yes & Yes & Yes \\
\hline
\end{tabular}


Novianto et al./ Health Management-Assisted Technology on Glycated Hemoglobin Levels

\begin{tabular}{|c|c|c|c|c|c|c|c|c|c|c|}
\hline $\begin{array}{l}\text { accounted for } \\
\text { in the conclu- } \\
\text { sions? Were } \\
\text { all patients } \\
\text { analyzed } \\
\text { according to } \\
\text { the rando- } \\
\text { mized study } \\
\text { groups? } \\
\text { What effect } \\
\text { size were } \\
\text { used? }\end{array}$ & $\begin{array}{c}\text { Mean } \\
\text { difference }\end{array}$ & $\begin{array}{c}\text { Mean } \\
\text { difference }\end{array}$ & $\begin{array}{c}\text { Mean } \\
\text { difference }\end{array}$ & $\begin{array}{c}\text { Mean } \\
\text { difference }\end{array}$ & $\begin{array}{c}\text { Mean } \\
\text { difference }\end{array}$ & $\begin{array}{c}\text { Mean } \\
\text { Difference }\end{array}$ & $\begin{array}{c}\text { Mean } \\
\text { Diference }\end{array}$ & $\begin{array}{c}\text { Mean } \\
\text { difference }\end{array}$ & $\begin{array}{c}\text { Mean } \\
\text { difference }\end{array}$ & $\begin{array}{c}\text { Mean } \\
\text { difference }\end{array}$ \\
\hline $\begin{array}{l}\text { Is the effect } \\
\text { statistically } \\
\text { significant? }\end{array}$ & $\begin{array}{c}\text { Not } \\
\text { Significant }\end{array}$ & $\begin{array}{c}\text { Not } \\
\text { significant }\end{array}$ & Significant & Significant & Significant & Significant & Significant & $\begin{array}{c}\text { Not } \\
\text { significant }\end{array}$ & $\begin{array}{c}\text { Not } \\
\text { significant }\end{array}$ & Significant \\
\hline $\begin{array}{l}\text { Are the } \\
\text { results appli- } \\
\text { cable to the } \\
\text { local popula- } \\
\text { tion or prac- } \\
\text { tice context? }\end{array}$ & Yes & Yes & Yes & Yes & Yes & Yes & Yes & Yes & Yes & Yes \\
\hline $\begin{array}{l}\text { Are all the } \\
\text { other clini- } \\
\text { cally import- } \\
\text { ant results } \\
\text { considered in } \\
\text { this article? }\end{array}$ & Yes & Yes & Yes & Yes & Yes & Yes & Yes & Yes & Yes & Yes \\
\hline $\begin{array}{l}\text { Do the bene- } \\
\text { fits provided } \\
\text { by the inter- } \\
\text { vention out- } \\
\text { weigh the } \\
\text { costs and } \\
\text { costs? }\end{array}$ & No & No & Yes & Yes & Yes & Yes & Yes & No & No & Yes \\
\hline
\end{tabular}


Table 2. Description of primary studies included in meta-analysis

\begin{tabular}{|c|c|c|c|c|c|c|c|}
\hline Author & Country & $\mathbf{P}$ & $\mathbf{I}$ & $\mathbf{C}$ & $\mathbf{O}$ & $\begin{array}{l}\text { Number of } \\
\text { Samples }\end{array}$ & $\begin{array}{l}\text { Length of } \\
\text { Study }\end{array}$ \\
\hline $\begin{array}{l}\text { Crowley et } \\
\text { al., } 2016\end{array}$ & United States & $\begin{array}{l}\text { Patients are Veterans } \\
\text { with type } 2 \text { diabetes and } \\
\text { HbA1c }>9 \%\end{array}$ & $\begin{array}{l}\text { Advanced Comprehensive } \\
\text { Diabetes Care (ACDC) by } \\
\text { Durham VHA Home } \\
\text { Telehealth (HT) }\end{array}$ & Usual care & $\begin{array}{l}\text { HbA1c } \\
\text { levels }\end{array}$ & 50 & 6 months \\
\hline $\begin{array}{l}\text { Heisler et al., } \\
2014\end{array}$ & United States & $\begin{array}{l}\text { Patients aged }>21 \text { years } \\
\text { old diagnosis type } 2 \\
\text { diabetes mellitus with } \\
\text { HbA1C } \geq 7.5 \%\end{array}$ & $\begin{array}{l}\text { Interactive web-based } \\
\text { tablet-delivered tool } \\
\text { (iDecide) }\end{array}$ & $\begin{array}{l}\text { Usual care } \\
\text { with printed } \\
\text { educational } \\
\text { materials }\end{array}$ & $\begin{array}{l}\text { HbA1c } \\
\text { levels }\end{array}$ & 188 & 3 months \\
\hline $\begin{array}{l}\text { Hsu et al., } \\
2016\end{array}$ & United States & $\begin{array}{l}\text { Patients } \geq 18 \text { years of age } \\
\text { with type } 2 \text { diabetes and } \\
\text { HbA1c } 9-14 \%\end{array}$ & $\begin{array}{l}\text { Computer tablet with } \\
\text { software diabetes } \\
\text { management program } \\
\text { was developed using } \\
\text { the Collabo Rhythm } \\
\text { software platform } \\
\text { designed at the MIT } \\
\text { Media Lab }\end{array}$ & $\begin{array}{l}\text { Received } \\
\text { standard } \\
\text { face-to-face } \\
\text { care }\end{array}$ & $\begin{array}{l}\text { HbA1c } \\
\text { levels }\end{array}$ & 40 & 3 months \\
\hline $\begin{array}{l}\text { Kempf et al., } \\
2017\end{array}$ & Germany & $\begin{array}{l}\text { Patients aged } 25 \text { to79 } \\
\text { years old diagnose type } 2 \\
\text { diabetes mellitus with } \\
\text { HbA1C } \geq 7.5 \%\end{array}$ & $\begin{array}{l}\text { Telemedical Lifestyle } \\
\text { intervention Program } \\
\text { (TeLiPro) }\end{array}$ & $\begin{array}{l}\text { Usual / } \\
\text { routine care }\end{array}$ & $\begin{array}{l}\text { HbA1c } \\
\text { levels }\end{array}$ & 202 & 52 weeks \\
\hline $\begin{array}{l}\text { Kleinman et } \\
\text { al., } 2017\end{array}$ & India & $\begin{array}{l}\text { Patients } 18-65 \text { years old } \\
\text { with type } 2 \text { diabetes and } \\
7.5 \% \leq \mathrm{HbA1c} \leq 12.5 \%\end{array}$ & $\begin{array}{l}\text { Gather Health, m-Health } \\
\text { diabetes management } \\
\text { platform, comprising a } \\
\text { smartphone app for } \\
\text { people with diabetes and } \\
\text { a Web portal and } \\
\text { smartphone app for } \\
\text { providers }\end{array}$ & Usual care & $\begin{array}{l}\text { HbA1c } \\
\text { levels }\end{array}$ & 91 & 6 months \\
\hline $\begin{array}{l}\text { Klingeman et } \\
\text { al., } 2017\end{array}$ & United States & $\begin{array}{l}\text { Patients with mean of } \\
\text { age } 54 \text { years old with }\end{array}$ & $\begin{array}{l}\text { Via emails or phone calls } \\
\text { and modified as needed }\end{array}$ & $\begin{array}{l}\text { Face-to-face } \\
\text { clinic visits }\end{array}$ & $\begin{array}{l}\text { HbA1c } \\
\text { levels }\end{array}$ & 60 & 6 months \\
\hline
\end{tabular}




\begin{tabular}{|c|c|c|c|c|c|c|c|}
\hline & & $\begin{array}{l}\text { type } 2 \text { diabetes with } \\
8 \% \leq \mathrm{HbA} 1 \mathrm{c} \leq 11 \%\end{array}$ & $\begin{array}{l}\text { while seeing the patient } \\
\text { once a year in the clinic }\end{array}$ & & & & \\
\hline $\begin{array}{l}\text { Nicolucci et } \\
\text { al., } 2015\end{array}$ & Italy & $\begin{array}{l}\text { Patients }>45 \text { years old } \\
\text { with type } 2 \text { diabetes and } \\
.5 \% \leq \mathrm{HbA} 1 \mathrm{c} \leq 10 \%\end{array}$ & A home telehealth (HT) & Usual care & $\begin{array}{l}\text { HbA1c } \\
\text { levels }\end{array}$ & 302 & 12 months \\
\hline $\begin{array}{l}\text { Tang et al., } \\
2013\end{array}$ & United States & $\begin{array}{l}\text { Patients } \geq 18 \text { years old } \\
\text { with type } 2 \text { diabetes and } \\
\text { HbA1c } \geq 7.5 \%\end{array}$ & $\begin{array}{l}\text { Engaging and Motivating } \\
\text { Patients Online with } \\
\text { Enhanced Resources for } \\
\text { Diabetes (EMPOWER-D) }\end{array}$ & Usual care & $\begin{array}{l}\text { HbA1c } \\
\text { levels }\end{array}$ & 382 & 12 months \\
\hline $\begin{array}{l}\text { Tildesley et } \\
\text { al., } 2013\end{array}$ & United States & $\begin{array}{l}\text { Patients with mean of } \\
\text { age } 58 \text { years old and } \\
\text { diagnosed type } 2 \text { dia- } \\
\text { betes and HbA1c }>7 \%\end{array}$ & $\begin{array}{l}\text { Internet blood glucose } \\
\text { monitoring system }\end{array}$ & $\begin{array}{l}\text { Usual care } \\
\text { with real } \\
\text { time conti- } \\
\text { nous glucose } \\
\text { monitoring }\end{array}$ & $\begin{array}{l}\text { HbA1c } \\
\text { levels }\end{array}$ & 57 & 6 months \\
\hline $\begin{array}{l}\text { Wild et al., } \\
2016\end{array}$ & $\begin{array}{l}\text { United } \\
\text { Kingdom }\end{array}$ & $\begin{array}{l}\text { Patients }>17 \text { years old } \\
\text { with type } 2 \text { diabetes and } \\
\text { HbA1c }>58 \mathrm{mmol} / \mathrm{mol} \\
(>7 \%)\end{array}$ & $\begin{array}{l}\text { Supported telemonitoring } \\
\text { intervention by website }\end{array}$ & Usual care & $\begin{array}{l}\text { HbA1c } \\
\text { levels }\end{array}$ & 321 & 9 months \\
\hline
\end{tabular}

\section{a. Forest Plot}

Interpretation of the results of a primary study on health management-assisted technology on HbA1c levels in patients with type 2 diabetes mellitus is shown in the Figure 3. The results of the forest plot above show that of the 10 articles that have been processed using RevMan 5.3 obtained significant results, this is shown from the overall effect (diamond) does not touch the vertical line $\mathrm{Ho}(\mathrm{d}=\mathrm{o})$ and can also be seen from the 95\% CI range of -0.62 to a -0.13 which indicates significant because it does not exceed the number o (SMD = -0.37; 95\% CI = -0.62 to -0.13 ; $\mathrm{p}=0.003$ ). The heterogeneity of the research data shows $\mathrm{I}^{2}=82 \%$ so that the distribution of the data is very heterogeneous (random effects model).

\section{a. Funnel plot}

Funnel plot is a diagram that depicts the estimated effect size of each study, where the accuracy is estimated using standard error.

Figure 4 shows a publication bias due to the asymmetric distribution of the plot. On the left side there are 4 plots with standard errors between 0.1 and 0.4 , on the right side there are 5 plots with standard errors between 0.1 and 0.3 , and there is 1 plot located in the middle. 
Novianto et al./ Health Management-Assisted Technology on Glycated Hemoglobin Levels

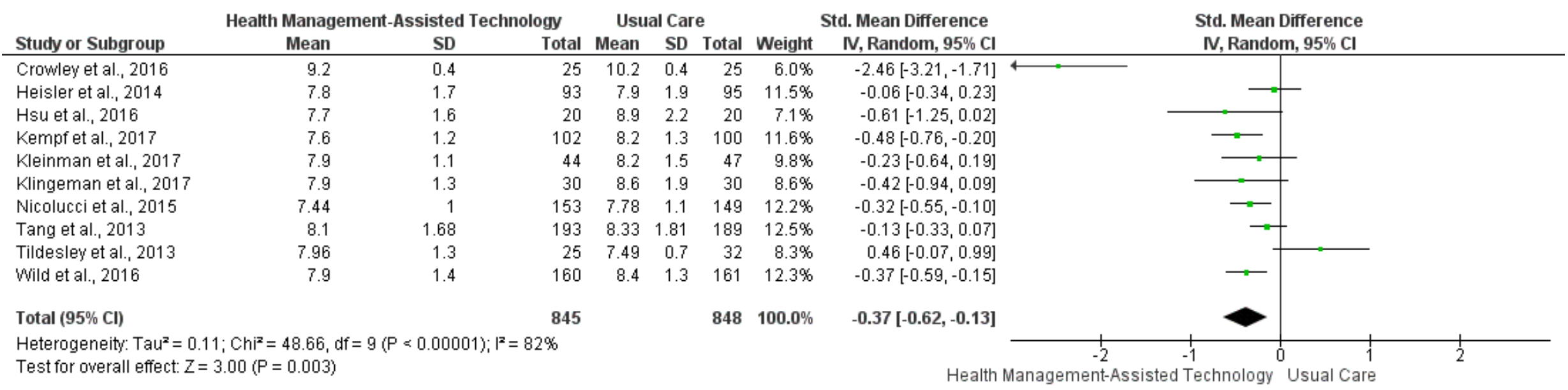

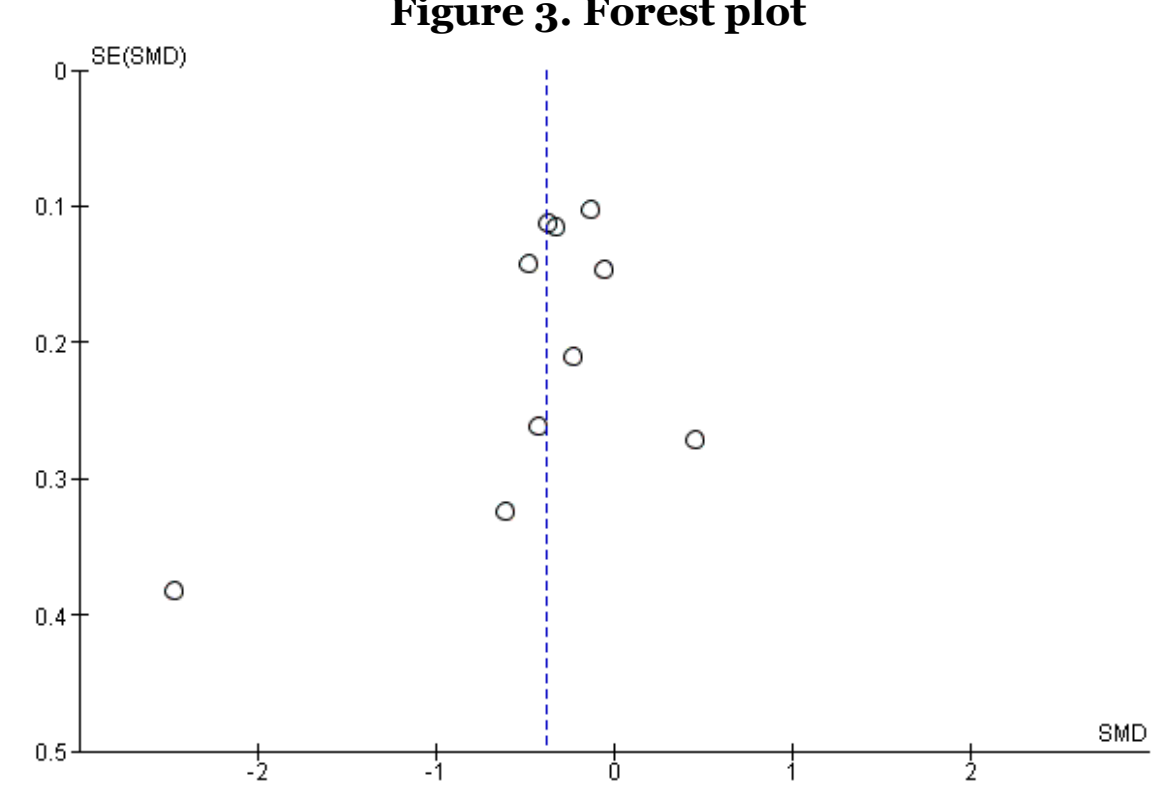

Figure 4. Funnel plot 


\section{DISCUSSION}

This systematic review and meta-analysis study raise the theme of the effect of technology use in health management on HbA1c levels in type 2 diabetes mellitus patients. This study discusses data on the use of technology in helping health management, especially in diabetes mellitus patients who have to do it routine control. The number of relevant research published and affordable is still small and also has data access problems (data duplication). Estimates of the combined effect of the use of health technology in patients with type 2 diabetes mellitus were processed using RevMan 5.3. Forest plots provide an overview of the information from each of the studies examined in the meta-analysis, and an estimate of the overall results (Murti, 2018).

According to Ministry of Health of the Republic of Indonesia (2018) the first behavior change communication strategy roadmap is to disseminate information in the field of communication such as the use of technology for information dissemination. A technology-based management of diabetes milletus type 2 treatment is important in an effort to reduce the cost of treating patients who come directly to health services. In addition, it is also important to monitor daily blood glucose levels and HbA1c levels which are indicators to measure the extent of the effectiveness of the management of therapy implemented and the risk of complications that may occur. Based on the results of a metaanalysis study using the Rev-man version 5.3 application above, it shows that there is a significant difference between health management assistive technology on medication adherence to type 2 diabetes mellitus patients. This significance provides an overview of the use of technology as a model of care for type 2 diabetes mellitus patients to undergo treatment. easier, more practical and cheaper. Through technology-based utilization in the treatment of type 2 diabetes mellitus patients, it is hoped that it can improve diabetes mellitus management which is important to do in order to achieve optimal glycemic control and prevent complications from type 2 diabetes mellitus.

Treatment of technology-based type 2 diabetes mellitus patients is part of health education regarding the care and prevention of complications of diabetes mellitus that need to be done. However, not all health facilities or clinics are able to provide education on diabetes mellitus care due to limited time from health workers, given the high working hours and workloads. In fact, according to Hsu et al. (2016) the use of technology is very important to be carried out in line with current advances in technology and is one of the means that can be used in the application of diabetes mellitus nursing care.

The factor that influences the effectiveness of the use of technology in the health sector is the increasing advancement of information technology which is already very supportive of health services and is supported by the latest research articles in medical journals which are published annually regarding the effectiveness of technology in improving the quality of health services. And health workers will quickly fall behind if they don't take advantage of various tools to update the latest developments. These two things illustrate that there is an effective use of technology, but there is a shortage of human resources as technology users which is a limitation of technology use, namely the time owned by health workers in the form of working hours and a fairly high work load. This is in line with the results of research by Nanditha et al. (2020) which states that electronic delivery of lifestyle and motivation advice may be less effective than if it is 
complemented by direct remote counseling or counseling. Long distance counseling is also hampered by the timing between the counselor and the recipient of the counseling itself.

However, there are many studies that show that diabetes mellitus treatment based on health management assistive technology is effective in reducing HbA1c levels and improving self-management of diabetes mellitus patients. Several previous research results show that diabetes mellitus treatment based on health management assistive technology provides effectiveness in reducing HbA1c levels and improving self-management of diabetes mellitus patients. Research on health management assisted technology includes research from Samudera (2020) concerning the Effectiveness of Mobile Health Intervention on SelfManagement and Glycemic Control in Patients with Type 2 Diabetes Mellitus with the results of mobile health intervention effective in improving self-management of diabetic patients and increasing medication adherence. In addition, mobile health intervention can also improve insulin levels and lipid profiles of type 2 diabetes mellitus patients. Technology-based diabetes mellitus treatment has many benefits and conveniences in providing nursing education or interventions without having to meet the patient directly, but self-management interventions are mostly patient. This is in line with the research of Oktovin et al. (2018) entitled The Use of Smartphones for the Program for Life Style Management Type 2 Diabetes Mellitus Patients with the results of the research that smartphone use is very effective especially in helping patients with type 2 diabetes mellitus to comply with their therapy program. Atmojo et al. (2020) also explained in their research that health services based on the use of information technology are an effective way to increase patient satisfaction.

Utilization of information technology and telecommunications, such as the use of cellphones, actually plays an important role in maximizing nursing care activities (Changizi and Kaveh, 2017), especially in terms of increasing adherence to therapy, for example for patients such as cardiovascular patients, high cholesterol diabetes and hypertension (Brath et al., 2013). The results of this study provide an explanation that health management assistive technology can be used as a medium for providing interventions that make it easier for patients and health workers to communicate and provide some important information related to the care and treatment of type 2 diabetes mellitus and can be used as a system that helps patients to adopt a lifestyle healthy. This meta-analysis study proves that utilizing technology to assist the health management of type 2 diabetes mellitus patients can reduce HbA1c levels with a Standardized Mean Different (SMD) of -0.37 compared to usual care (SMD = $0.37 ; 95 \% \mathrm{CI}=-0.62$ to $-0.13 ; \mathrm{p}=0.003)$.

\section{AUTHOR CONTRIBUTION}

All authors have a role in selecting topics, tracking, collecting data, reviewing study documents, and analyzing data.

\section{CONFLICT OF INTEREST}

There is no conflict of interest in this study.

\section{FUNDING AND SPONSORSHIP}

There was no external fund.

\section{ACKNOWLEDGEMENT}

We would like to thank the journal databases of PubMed, Google Scholar, and ResearchGate. 


\section{REFERENCE}

Atmojo J, Sudaryanto W, Widiyanto A, Ernawati, Arradini D (2020). Telemedicine, cost effectiveness, and patients satisfaction: A systematic review. J Health Policy Manage. 5(2): 103107. https://doi.org/10.26911/thejhpm.2020.05.02.02.

Brath H, Morak J, Kästenbauer T, ModreOsprian R, Strohner-Kästenbauer H, Schwarz M, Kort W, et al. (2013). Mobile health (mHealth) based medication adherence measurement - a pilot trial using electronic blisters in diabetes patients. British Journal of Clinical Pharmacology, 76(1): 47-55. https://doi.org/10.1111/bcp.12184

Changizi M, Kaveh MH (2017). Effectiveness of the mHealth technology in improvement of healthy behaviors in an elderly population-a systematic review. MHealth, 3(51). https://doi.org/10.21037/mhealth.2017.08.06

Crowley MJ, Edelman D, McAndrew AT, Kistler S, Danus S, Webb JA, Zanga J et al. (2016). Practical telemedicine for veterans with persistently poor diabetes control: A randomized pilot trial. Telemedicine and E-Health, 22(5): 376-384. https://doi.org/10.1089/tmj.2015.0145.

Fountoulakis S, Papanastasiou L, Gryparis A, Markou A, Piaditis G (2015). Impact and duration effect of telemonitoring on $\mathrm{HbA1c}, \mathrm{BMI}$ and cost in insulin-treated diabetes mellitus patients with inadequate glycemic control: A randomized controlled study. Hormones, 14(4): 632-643. https://doi.org/10.14310/horm.2002.1603.

Heisler M, Choi H, Palmisano G, Mase R, Richardson C, Fagerlin A, Montori $\mathrm{VM}$ et al. (2014). Comparison of community health worker-led diabetes medication decision-making support for low-income Latino and African American adults with diabetes using e-Health tools versus print materials: A randomized controlled trial. Ann Intern Med, 161(100). S13 - S22. https://doi.org/doi:10.7326/M13-3012.

Hsu WC, Lau KHK, Huang R, Ghiloni S, Le $\mathrm{H}$, Gilroy S, Abrahamson $\mathrm{M}$ et al. (2016). Utilization of a cloud-based diabetes management program for insulin initiation and titration enables collaborative decision making between healthcare providers and patients. Diabetes Technology and Therapeutics. 18(2): 59-67. https://doi.org/10.1089/dia.2015.0160.

Kempf K, Altpeter B, Berger J, Reuß O, Fuchs M, Schneider M, Gärtner B, et al. (2017). Efficacy of the telemedical lifestyle intervention program TeLiPro in advanced stages of type 2 diabetes: A randomized controlled trial. Diabetes Care. 40(7): 863-871. https://doi.org/10.2337/dc17-0303.

Kleinman NJ, Shah A, Shah S, Phatak S, Viswanathan V (2017). Improved medication adherence and frequency of blood glucose self-testing using an $\mathrm{m}$-health platform versus usual care in a multisite randomized clinical trial among people with type 2 diabetes in India. Telemedicine Journal and EHealth: The Official Journal of the American Telemedicine Association. 23(9): 733-740. https://doi.org/10.1089/tmj.2016.0265.

Klingeman H, Funnell M, Jhand A, Lathkar-Pradhan S, Hodish I (2017). Type 2 diabetes specialty clinic model for the accountable care organization era. Journal of Diabetes and Its Complications, 31(10): 1521-1526. https://doi.org/10.1016/j.jdiacomp.2017.05.0 11. 
Novianto et al./ Health Management-Assisted Technology on Glycated Hemoglobin Levels

Ministry of Health RI (2018). Infodatin center for data and information of the Ministry of Health of the Republic of Indonesia. World Diabetes Day. Ministry of Health of the Republic of Indonesia.

Murti B (2018). Epidemiological Research Principles and Methods. (V). Bintang Fajar Offsite Colomadu.

Nanditha A, Thomas H, Susairaj P, Srivanichakorn W, Oliver N, Godsland IF, Majeed A, et al. (2020). Pragmatic and scalable strategies using cellular technology to promote sustainable lifestyle changes to prevent type 2 diabetes in India and UK. Diabetalogia, 63: 489-496. https://doi.org/10.1007/s00125-019-05061-y.

Nicolucci A, Cercone S, Chiriatti A, Muscas F, Gensini G, Fucito G, Gambini A, et al. (2015). A randomized trial on home telemonitoring for the management of metabolic and cardiovascular risk in patients with type 2 diabetes. Diabetes Technology and Therapeutics. 17(8): 563-570. https://doi.org/10.1089/dia.2014.0355.

Oktovin O, Unja EE, Rachman A (2018). Systematic review: Use of smartphones for life style management programs for type 2 diabetes mellitus patients. JKSI. 3(2): 1-10. https://doi.org/10.51143/jksi.v3i2.102.

Ramadhan N, Marissa N (2015). Characteristics of type 2 diabetes mellitus patients based on HbA1c levels at the Jayabaru Community Health Center, Banda Aceh City. SEL. 2(2): 49-56.

Ocean WS (2020). Effectiveness of mobile health intervention on self-management and glycemic control in patients with type 2 diabetes mellitus: A systematic review. Forikes Journal of Sound Health Research. 4(11).

Tang P, Overhage JM, Chan AS, Brown NL, Aghighi B, Entwistle MP, Hui SL, et al. (2013). Online disease management of diabetes: engaging and motivating patients online with enhanced resources-diabetes (EMPOWER-D), a randomized controlled trial. Journal of the American Medical Informatics Association. 20(3): 526-524. https://doi.org/10.1136/amiajnl-2012-oo1263.

Tildesley HD, Wright AM, Chan JHM, Mazanderani AB, Ross SA, Tildesley HG, Lee AM, et al. (2013). A comparison of internet monitoring with continuous glucose monitoring in insulinrequiring type 2 diabetes mellitus. Canadian Journal of Diabetes. 37(5): 305-308. https://doi.org/10.1016/j.jcjd.2013.05.006.

WHO (2019). Classification of diabetes mellitus. World Health Organization. https://www.who.int/publications/i/i tem/classification-of-diabetes-mellitus.

Wild SH, Hanley J, Lewis SC, McKnight JA, McCloughan LB, Padfield PL, Parker $\mathrm{R}$, et al. (2016). Supported telemonitoring and glycemic control in people with type 2 diabetes: The telescot diabetes pragmatic multicenter randomized controlled trial. https://doi.org/10.1371/journal.pmed.1002098. 